\title{
Effect of normobaric oxygen treatment on oxidative stress and enzyme activities in guinea pig heart
}

\author{
Zuzana Tatarkova ${ }^{1}$, Ivan Engler ${ }^{2}$, Andrea Calkovska ${ }^{3}$, Daniela Mokra ${ }^{3}$, Anna Drgova ${ }^{1}$, Stanislav \\ Kuka $^{1}$, Peter Racay ${ }^{1}$, Jan Lehotsky ${ }^{1}$, Dusan Dobrota ${ }^{1}$ and Peter Kaplan ${ }^{1}$ \\ ${ }^{1}$ Department of Medical Biochemistry, Jessenius Faculty of Medicine, Comenius University, Martin, Slovak Republic \\ ${ }^{2}$ Department of Physiology, Medical Faculty, P. J. Safarik University, Kosice, Slovak Republic \\ ${ }^{3}$ Department of Physiology, Jessenius Faculty of Medicine, Comenius University, Martin, Slovak Republic
}

\begin{abstract}
Normobaric oxygen (NBO) therapy is commonly applied for the treatment of various diseases, including myocardial infarctions, but its effectiveness is controversial. Potential adverse effects of hyperoxia are related to excessive formation of free radicals. In the present study we examined the effect of 60-h NBO treatment on lipid peroxidation (LPO), activity of manganese superoxide dismutase (Mn-SOD) and mitochondrial enzymes of energy metabolism in guinea pig heart. NBO treatment resulted in significant accumulation of thiobarbituric acid reactive substances and loss of Mn-SOD activity despite slight elevation of Mn-SOD protein content. Activity of electron transport chain complex III decreased significantly, while activity of complex IV was slightly elevated and citrate synthase was unchanged. LPO, inhibition of Mn-SOD and complex III activities were more pronounced when inhaled oxygen was partially enriched with superoxide radical. In contrast, when $\mathrm{O}_{2}$ was enriched with oxygen cation $\left(\mathrm{O}_{2}{ }^{-+}\right)$, LPO and loss of Mn-SOD activity were prevented. Complex III activity in the $\mathrm{O}_{2}{ }^{\bullet+}$-treated group remained depressed but activities of complex IV and citrate synthase were elevated. These data suggest that NBO treatment is associated with myocardial oxidative damage and attenuation of antioxidant defense, but these adverse effects can be partially attenuated by inhalation of $\mathrm{O}_{2}$ enriched with oxygen cation.
\end{abstract}

Key words: Normobaric oxygen - Heart — Mitochondria - ROS - Oxidative stress

Abbreviations: EDTA, ethylene diamine tetra-acetic acid; GPx, glutathione peroxidase; HBO, hyperbaric oxygenation; LPO, lipid peroxidation; MDA, malondialdehyde; NBO, normobaric oxygenation; ROS, reactive oxygen species; SDS, sodium dodecyl sulfate; SOD, superoxide dismutase; TBARS, thiobarbituric acid reactive substances.

\section{Introduction}

Normobaric (NBO) and hyperbaric oxygenation $(\mathrm{HBO})$ are noninvasive medical treatments based on inhalation of $100 \%$ oxygen at an atmospheric pressure or at pressure higher than normal atmospheric pressure, respectively. They have been applied for the treatment and detection of various diseases and clinical conditions related to hypoxia, including myocar-

Correspondence to: Peter Kaplan, Department of Medical Biochemistry, Jessenius Faculty of Medicine, Comenius University, Mala Hora 4, 03601 Martin, Slovak Republic

E-mail: kaplan@jfmed.uniba.sk dial infarction (Dekleva et al. 2009). Recently it has been suggested that excessive use of supplemental oxygen may worsen outcomes in a number of patients (Moradkhan and Sinoway 2010). Although NBO is generally better tolerated than $\mathrm{HBO}$, the exposure to high oxygen concentration was shown to be associated with various adverse effects including coronary vasoconstriction, decreased cardiac output and reperfusion injury post-myocardial infarction (Howard 2009). The molecular mechanisms responsible for side effects of hyperoxia are not yet fully understood, however, excessive formation of reactive oxygen species (ROS) has been proposed as one of potential factors mediating damaging effects (Narkowicz et al. 1993). In animal studies, it was shown that oxygenation 
treatment significantly increases lipid and protein oxidative damage in the heart, brain and other organs and tissues (Hensley et al. 1995; Chavko and Harabin 1996; Ay et al. 2007; Kaplan et al. 2009; Tatarkova et al. 2011). However, few studies that have investigated the efficacy of antioxidant treatment are controversial. In rodent models, the protective effects of exogenously administrated melatonin (Dundar et al. 2005) and vitamins $C$ and $E$ (Brozmanova et al. 2006) were shown. In healthy men, the infusion of vitamin $\mathrm{C}$ was shown to prevent hyperoxia-induced coronary vasoconstriction and impairment of myocardial function (Gao et al. 2011) but another studies suggest that supplementation with vitamin $\mathrm{E}$, vitamin $\mathrm{C}$ plus $\mathrm{E}$ or with $\mathrm{N}$-acetylcysteine are unable to prevent NBO- and HBO-induced lipid and nucleic acid oxidative damage (Dennong et al. 1999; Bader et al. 2007). Controversy exists also regarding the effects of hyperoxia on endogenous antioxidants. $\mathrm{HBO}$ and $\mathrm{NBO}$ treatments were shown to stimulate activities of superoxide dismutase (SOD) and glutathione peroxidase (GPx) in brain and skeletal muscle (Gregorevic et al. 2001; Ay et al. 2007; Tatarkova et al. 2011). On the other hand, SOD, GPx and catalase activities in erythrocytes were not affected by $\mathrm{HBO}$ (Dennong et al. 1999; Eken et al. 2005). Studies examining effect of oxygenation treatments on endogenous antioxidants in other tissues and organs, including the heart are lacking.

It is well established that mitochondria are the major intracellular source of ROS and their production progressively increases with increasing partial pressure of $\mathrm{O}_{2}$ (Boveris and Chance 1973). Recently we have shown that long-term NBO treatment significantly reduces $\alpha$-ketoglutarate dehydrogenase activity in mitochondria of guinea pig heart, but when inhaled $\mathrm{O}_{2}$ was enriched with oxygen cation, $\mathrm{O}_{2}{ }^{\bullet+}$, loss of activity was prevented (Kaplan et al. 2009). The effect of $\mathrm{NBO}$ with or without $\mathrm{O}_{2}{ }^{\bullet+}$ on other mitochondrial enzymes is unknown.

Therefore, the objective of present study was to compare the effects of long-term NBO treatment with pure oxygen and NBO treatments with oxygen enriched with oxygen cation or superoxide radical on activities and protein contents of manganese superoxide dismutase (Mn-SOD) and enzymes of energy metabolism in guinea pig heart.

\section{Materials and Methods}

\section{Animals and NBO treatment}

All animal experiments conform to the "Guide for the Care and Use of Laboratory Animals" published by The US National Institute of Health (NIH publication No. 85-23, revised 1996), and the ethical guidelines of the Jessenius Faculty of Medicine, Comenius University (Martin, Slovak Republic).
Twenty male Trik guinea pigs weighing 250-350 g were used in these studies. The NBO-treated animals were kept in a sealed metabolic chamber and exposed to $100 \%$ molecular oxygen $\left(\mathrm{NBO}-\mathrm{O}_{2}\right), \mathrm{O}_{2}$ enriched with superoxide radical $\left(\mathrm{NBO}-\mathrm{O}_{2}{ }^{--}\right)$or $\mathrm{O}_{2}$ enriched with oxygen cation radical $\left(\mathrm{NBO}-\mathrm{O}_{2}{ }^{\bullet+}\right.$ ) for $60 \mathrm{~h}$ as described previously (Tatarkova et al. 2011). The $\mathrm{O}_{2}$ concentration was monitored periodically by an oxygen analyzer (Permolyt 3, Veb Junkalor, Germany). Partial and unipolar ionization of medical $\mathrm{O}_{2}$ was induced between two electrodes with $15 \mathrm{kV}$ as described previously Engler et al. (2009) using plasma chamber Oxygen Ion 3000 (CStronic GmBH, Austria), which is an European Union certified medical therapeutic device. The untreated control animals were also placed in a metabolic chamber and were breathing atmospheric air. Lethal dose of anaesthetics was given to animals at the end of experimental procedure. Hearts were immediately washed with physiological solution and stored at $-80^{\circ} \mathrm{C}$ until use.

Preparation of heart homogenate and isolation of mitochondria

Frozen powdered tissue of the whole heart was thawed in 10 volumes of ice-cold homogenization buffer $(30 \mathrm{mmol} / \mathrm{l}$ $\mathrm{KH}_{2} \mathrm{PO}_{4}, 5 \mathrm{mmol} / 1$ EDTA, $0.3 \mathrm{~mol} / 1$ sucrose, $\mathrm{pH} 7.0$ ) with $0.3 \mathrm{mmol} / \mathrm{l}$ phenylmethylsulfonyl fluoride (PMSF) and homogenized in Potter-Elvehjem homogenizer. Mitochondria were isolated from individual heart homogenates by differential centrifugation as previously described Babusikova et al. (2004).

\section{Lipid peroxidation measurement}

Lipid peroxidation (LPO) product, free and protein-bound malondialdehyde (MDA), was estimated in the heart homogenates according to the formation of thiobarbituric acid reactive substances (TBARS). Briefly, $0.05 \mathrm{ml}$ of homogenate was added to the test tube containing $1 \mathrm{ml}$ of $14 \%$ acetic acid solution and $1 \mathrm{ml}$ of $0.67 \%$ TBA. The mixture was heated at $80^{\circ} \mathrm{C}$ for $30 \mathrm{~min}$ and cooled on ice $(5 \mathrm{~min})$. After centrifugation at 2,000 $\times g$ for $10 \mathrm{~min}$, the organic phase was collected and the absorbance measured at a wavelength of $535 \mathrm{~nm}$. The results were expressed as nmol MDA/mg protein.

\section{Measurement of enzyme activities}

Mn-SOD activity was determined from the inhibition of nitroblue tetrazolium (NBT) by superoxide anion produced by xanthine oxidase. The reaction mixture contained $0.05 \mathrm{mM}$ phosphate buffer (pH 7.8), $0.1 \mathrm{mmol} / \mathrm{l} \mathrm{EDTA}, 0.025 \mathrm{mmol} / \mathrm{l}$ NBT and $0.1 \mathrm{mmol} / \mathrm{l}$ xanthine. The absorbance change was monitored at $550 \mathrm{~nm}$ against a control. One unit of SOD activity is defined as the amount of enzyme causing 50\% inhibition of NBT reduction. 
Cytochrome $c$ reductase (complex III) activity was determined as the rate of antimycin A-dependent reduction of cytochrome $c$ at $550 \mathrm{~nm}\left(\varepsilon=18.5 \mathrm{mmol}^{-1} \cdot \mathrm{cm}^{-1}\right)$ (Nulton-Persson and Szweda 2001). Mitochondria ( $0.05 \mathrm{mg}$ protein per $\mathrm{ml}$ ) were incubated at $30^{\circ} \mathrm{C}$ in medium containing $35 \mathrm{mmol} / 1 \mathrm{KH}_{2} \mathrm{PO}_{4}$ ( $\mathrm{pH}=7.2), 5 \mathrm{mmol} / 1 \mathrm{MgCl}_{2}, 2 \mathrm{mmol} / \mathrm{l} \mathrm{KCN}$ and $0.05 \%$ Triton $\mathrm{X}-100$. The reaction was started with $60 \mu \mathrm{mol} / \mathrm{l} \mathrm{M}$ reduced decylubiquinone and $50 \mu \mathrm{mol} / \mathrm{l}$ of cytochrome $c$.

Cytochrome $c$ oxidase (complex IV) activity was measured spectrophotometrically by measuring the rate of cytochrome $c$ oxidation at $550 \mathrm{~nm}\left(\varepsilon=19.6 \mathrm{mmol}^{-1} \cdot \mathrm{cm}^{-1}\right)$ (Racay et al. 2009). Mitochondria ( $0.05 \mathrm{mg}$ protein $/ \mathrm{ml}$ ) were incubated at $30^{\circ} \mathrm{C}$ in medium containing $50 \mathrm{mM}$ Tris- $\mathrm{HCl}$ $(\mathrm{pH} 8.0), 0.01 \%(\mathrm{w} / \mathrm{v}) \mathrm{n}$-dodecyl $\beta$-D-maltoside. The reaction was started by addition of reduced cytochrome $c$ to the final concentration $0.05 \mathrm{mmol} / \mathrm{l}$. Final activity was expressed as nmol of cytochrome $c$ per minute per $\mathrm{mg}$ of protein.

Citrate synthase activity was determined spectrophotometrically according to commercial Citrate Synthase Kit - CS 0720 (Sigma).

\section{Western blot analysis of Mn-SOD}

For detection of Mn-SOD cardiac proteins $(30 \mu \mathrm{g})$ were separated on $10 \%$ SDS-polyacrylamide gels under denaturing conditions and then transferred to Immobilon-P transfer membranes (Millipore, Bedford, USA) using Mini Trans-Blot cell. Each membrane was blocked with $5 \%$ non-fat blocking-grade milk in TBS-T (Tris base saline and $0.05 \%$ Tween 20) overnight. The membranes were then incubated with monoclonal anti-SOD-2 (A2) antibody (Santa Cruz Biotechnology) (1:500) for $1 \mathrm{~h}$. After washing with TBS-T the blots were incubated with horseradish peroxidase-conjugated anti-mouse secondary antibody (Cell Signaling, 1:2000) for $1 \mathrm{~h}$. The immunoreactive proteins were visualized using the SuperSignal West Pico Chemiluminescent Substrate (Pierce) solution for $5 \mathrm{~min}$. After exposition of membranes on Chemidoc XRS (BioRad), the corresponding bands were integrated using GeneTools software (SynGene).

\section{Statistical analysis}

Data are expressed as mean \pm SEM. One-way analysis of variance with post-hoc comparisons by Student-Neuman-Keuls test was carried out to test for differences among groups (GrafPhad Software). A value of $p<0.05$ was considered to be statistically significant.

\section{Results}

The effect of 60-h NBO treatments on LPO is shown in the Table 1. The TBARS content in heart homogenates of
Table 1. Effect of NBO treatments on lipid peroxidation and citrate synthase activity

\begin{tabular}{|c|c|c|}
\hline Treatment & $\begin{array}{c}\text { TBARS } \\
\text { (nmol/mg protein) }\end{array}$ & $\begin{array}{c}\text { Citrate synthase } \\
\text { (nmol/min/mg protein) }\end{array}$ \\
\hline Air & $1.26 \pm 0.13$ & $801 \pm 18$ \\
\hline $\mathrm{NBO}-\mathrm{O}_{2}$ & $1.59 \pm 0.05^{*}$ & $792 \pm 9$ \\
\hline $\mathrm{NBO}-\mathrm{O}_{2} \cdot-$ & $1.76 \pm 0.04^{* * *}$ & $786 \pm 19$ \\
\hline $\mathrm{NBO}-\mathrm{O}_{2}{ }^{++}$ & $1.02 \pm 0.03^{\# \# \#}$ & $910 \pm 16^{* * * \# \# \#}$ \\
\hline
\end{tabular}

Values are expressed as means $\pm \operatorname{SEM}(n=5) .{ }^{\star} p<0.05 ;{ }^{* * *} p<$ 0.001 , significantly different when compared to the air-treated group; ${ }^{\# \#} p<0.001$, significantly different when compared to $\mathrm{NBO}-\mathrm{O}_{2}$-treated group.

guinea pigs which inhaled molecular oxygen $\left(\mathrm{NBO}-\mathrm{O}_{2}\right)$ was significantly greater then those in control guinea pigs which inhaled atmospheric air (by $26 \pm 4 \%, p<0.05$ ). When inhaled $\mathrm{O}_{2}$ was enriched with superoxide radical (NBO$\mathrm{O}_{2}{ }^{--}$), the increase was considerably greater (by $40 \pm 3 \%$, $p<0.001)$. However, enrichment of $\mathrm{O}_{2}$ with oxygen cation radical $\left(\mathrm{NBO}-\mathrm{O}_{2}{ }^{++}\right)$was associated with reduced formation of TBARS ( $81 \pm 3 \%$ of control).

To assess whether NBO-induced oxidative stress is related to alterations in antioxidant defense, the Mn-SOD activity was determined. As shown in Fig. 1, Mn-SOD activity in $\mathrm{NBO}-\mathrm{O}_{2}$ group was significantly decreased (by $19 \pm 9 \%$, $p<0.05)$. After $\mathrm{NBO}-\mathrm{O}_{2}{ }^{\bullet+}$ treatment it was also lowered (by $12 \pm 9 \%$ ), but this change was not significant. However, in $\mathrm{NBO}-\mathrm{O}_{2}{ }^{\circ-}$-treated group the activity decreased by $48 \pm$ $7 \%(p<0.001)$. Monoclonal antibody against Mn-SOD was

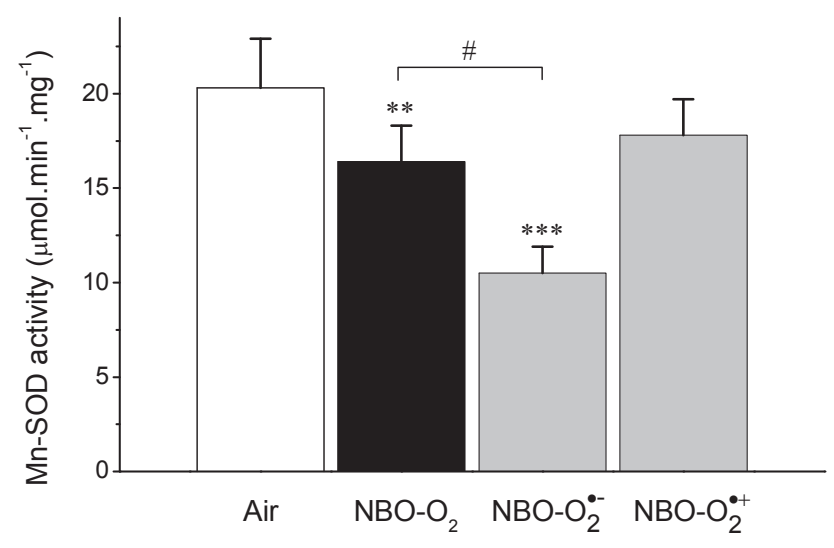

Figure 1. Effect of $60 \mathrm{~h}$ normobaric oxygen treatments on the $\mathrm{Mn}-\mathrm{SOD}$ activity. $\mathrm{NBO}-\mathrm{O}_{2}, 100 \%$ molecular oxygen; $\mathrm{NBO}-\mathrm{O}_{2}{ }^{\bullet-}$, $\mathrm{O}_{2}$ enriched with superoxide radical $\left(\mathrm{NBO}-\mathrm{O}_{2}{ }^{--}\right) ; \mathrm{NBO}^{-} \mathrm{O}_{2}{ }^{\bullet+}, \mathrm{O}_{2}$ enriched with oxygen cation radical. Values are given means \pm $\operatorname{SEM}(n=5){ }^{* *} p<0.01 ;{ }^{* * *} p<0.001$, significantly different when compared to the air-treated group; ${ }^{\#} p<0.05$, significantly different when compared to $\mathrm{NBO}-\mathrm{O}_{2}$-treated group. 


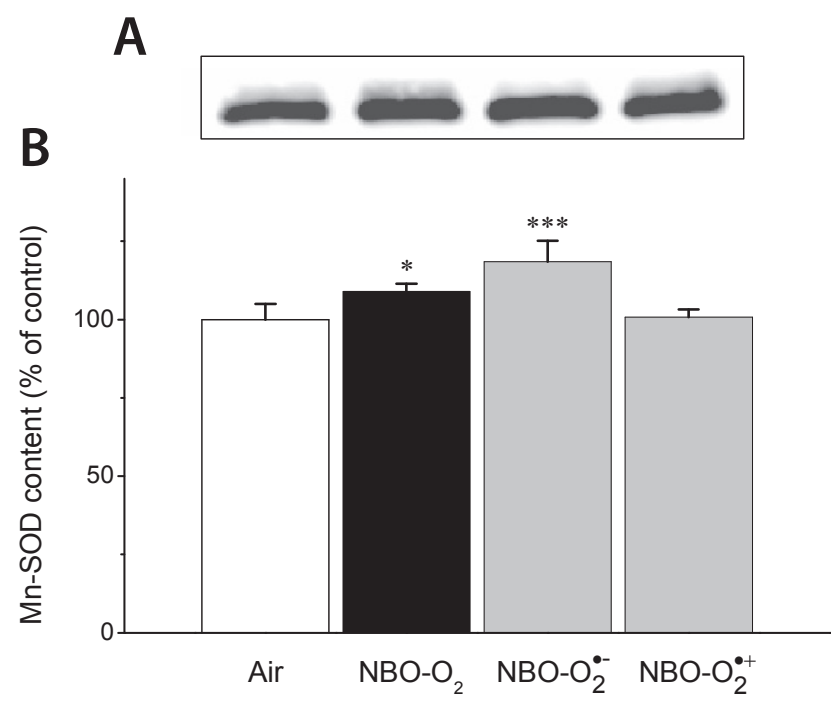

Figure 2. Representative Western blot (A) and densitometry analysis (B) of Mn-SOD immunoreactive band from hearts of $\mathrm{NBO}^{-} \mathrm{O}_{2}$-, $\mathrm{NBO}-\mathrm{O}_{2}{ }^{--}$- and $\mathrm{NBO}-\mathrm{O}_{2}{ }^{-+}$-treated guinea pigs. Values are given means $\pm \operatorname{SEM}(n=5){ }^{*} p<0.05$; ${ }^{* *} p<0.001$, significantly different when compared to the air-treated group.

used to assess antioxidant enzyme content. There were slight elevations of $\mathrm{Mn}-\mathrm{SOD}$ content in $\mathrm{NBO}-\mathrm{O}_{2}$ - and $\mathrm{NBO}-\mathrm{O}_{2}{ }^{-{ }^{-}}$treated groups (by $9 \pm 3 \%, p<0.01$ and $19 \pm 7 \%, p<0.01$, respectively). In animals treated with $\mathrm{NBO}-\mathrm{O}_{2}{ }^{\bullet+}$ the enzyme content was not changed (Fig. 2).

The effects of NBO treatments on energy metabolism of the heart was evaluated according to enzyme activities of citrate synthase, cytochrome $c$ reductase and cytochrome $c$ oxidase. There were no effects of $\mathrm{NBO}-\mathrm{O}_{2}$ and $\mathrm{NBO}-\mathrm{O}_{2}{ }^{--}$treatments on citrate synthase activity, but $\mathrm{NBO}-\mathrm{O}_{2}{ }^{\bullet+}$ caused significant stimulation of this enzyme (by $44 \pm 1 \%, p<0.001$ ) (Table 1 ). On the other hand, activity of cytochrome $c$ reductase was depressed in all NBO groups, but to a different extent (Fig. 3). While in NBO-O ${ }_{2}$ and NBO- $\mathrm{O}_{2}{ }^{\bullet+}$ groups the cytochrome $c$ reductase was lower by $25 \pm 3 \%(p<0.01)$ and $30 \pm 5 \%(p<0.01)$, respectively, in NBO-O ${ }_{2}{ }^{--}$group it decreased by $80 \pm 1 \%(p<0.001)$. Also cytochrome $c$ oxidase was significantly changed by NBO treatments (Fig. 4). This enzyme was slightly stimulated in $\mathrm{NBO}-\mathrm{O}_{2}$ and $\mathrm{NBO}-\mathrm{O}_{2}{ }^{\bullet+}$ groups (by $7 \pm 2 \%, p<0.01$ and $9 \pm$ $3 \%, p<0.01$, respectively) and inhibited in $\mathrm{NBO}-\mathrm{O}_{2}{ }^{--}$group (by $20 \pm 3 \%, p<0.001$ ).

\section{Discussion}

Accumulating evidence supports the role of ROS in both, positive and adverse effects of oxygen therapy. Among other cellular structures mitochondria are particularly vulnerable to oxidative damage because of increased formation of ROS with rising partial pressure of oxygen (Boveris and Chance 1973). Our previous studies have indicated that long-term exposure to $\mathrm{NBO}-\mathrm{O}_{2}$ induces accumulation of lipid and protein oxidative damage in the heart mitochondria (Kaplan et al. 2009). Furthermore, NBO-O ${ }_{2}$ treatment was shown to inhibit $\alpha$-ketoglutarate dehydrogenase activity. In the present study $\mathrm{NBO}-\mathrm{O}_{2}$ treatment was used as a model to study effect of hyperoxia on mitochondrial enzymes of energy metabolism and Mn-SOD. Using TBARS test we confirmed that $\mathrm{NBO}-\mathrm{O}_{2}$ exposure resulted in the increased LPO. Enrichment of oxygen with superoxide radical resulted in increased formation of LPO end products and gave another indirect evidence for the involvement of normobaric hyperoxia in cardiac oxidative stress. In contrast, the extent of TBARS formation after inhalation of $\mathrm{O}_{2}$ enriched with oxygen cation was even lower than after inhalation of atmospheric air. These results are in agreement with our previous studies showing decreased formation of conjugated dienes and indicate the ability of $\mathrm{O}_{2}{ }^{\cdot+}$ to attenuate oxidative stress in the heart. It has been suggested that hyperoxic treatment induces adaptive protection through stimulation of antioxidant enzymes in brain (Bigdeli and Rahnema 2009; Kaplan et al. 2009). To evaluate the role of this mechanism in the heart we determined protein content and activity of the main mitochondrial antioxidant enzyme Mn-SOD. Our results show that the expression of Mn-SOD was increased after $60-\mathrm{h} \mathrm{NBO}-\mathrm{O}_{2}$ treatment. The Mn-SOD expression was even higher when inhaled oxygen was enriched with superoxide radical. These results support the view that oxidative stress upregulates antioxidant defense system. Interestingly, this upregulation was not manifested in the increase

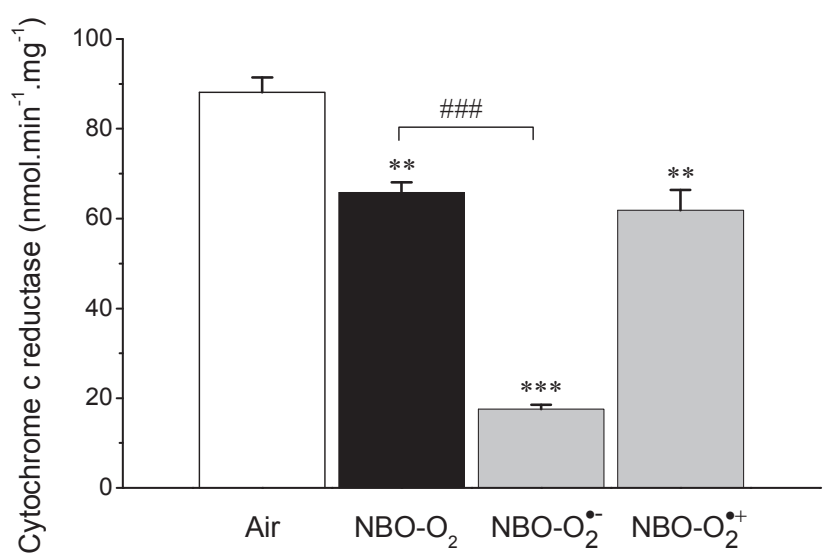

Figure 3. Effect of $\mathrm{NBO}-\mathrm{O}_{2}, \mathrm{NBO}-\mathrm{O}_{2}{ }^{\cdot-}$ and $\mathrm{NBO}-\mathrm{O}_{2}{ }^{\bullet+}$ treatment on the activity of cytochrome $c$ reductase. Values are given means \pm SEM $(n=5) .{ }^{* *} p<0.01 ;{ }^{* *} p<0.001$, significantly different when compared to the air treated group; ${ }^{\# \#} p<0.001$, significantly different when compared to $\mathrm{NBO}-\mathrm{O}_{2}$-treated group. 


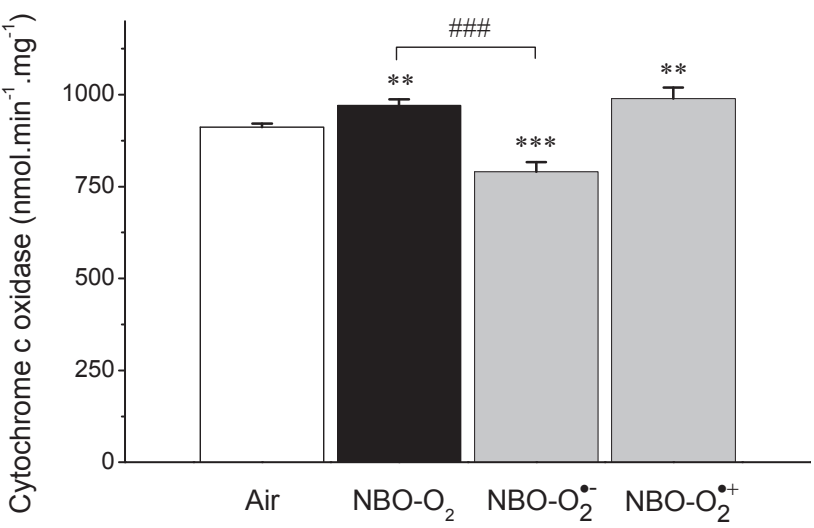

Figure 4. Effect of $\mathrm{NBO}-\mathrm{O}_{2}, \mathrm{NBO}-\mathrm{O}_{2}{ }^{\cdot-}$ and $\mathrm{NBO}-\mathrm{O}_{2}{ }^{\bullet+}$ treatment on the activity of cytochrome $c$ oxidase. Values are given means $\pm \operatorname{SEM}(n=5) .{ }^{* *} p<0.01 ;{ }^{* *} p<0.001$, significantly different when compared to the air-treated group; ${ }^{\# \# \# ~} p<0.001$, significantly different when compared to $\mathrm{NBO}-\mathrm{O}_{2}$-treated group.

of enzyme activity. In the opposite, Mn-SOD activity was slightly depressed after $\mathrm{NBO}-\mathrm{O}_{2}$ treatment and in NBO$\mathrm{O}_{2}{ }^{--}$group it reached only half of control. Depressed activity occurring at higher Mn-SOD content can be explained by post-translational modification of protein since this enzyme is highly vulnerable to oxidative/nitrative stress (Yamakura and Kawasaki 2010). Decreased Mn-SOD activity caused by post-translational modification was found in acutely rejecting cardiac transplants (Nilakantan et al. 2005). Increased Mn-SOD protein content but loss in the enzyme activity was also observed in chronic rejection of human renal allograft (MacMillan-Crow et al. 1996). Using immunoprecipitation and amino acid sequencing analysis tyrosine nitration by peroxynitrite was identified as a mechanism of enzyme inactivation. Protein modifications were not examined in the present study; however, previously we have shown that 60 -h NBO- $\mathrm{O}_{2}$ and NBO- ${ }_{2}{ }^{--}$treatments cause substantial accumulation of amino acid oxidative lesions, including tyrosine modification (Kaplan et al. 2009), which could contribute to enzyme dysfunction.

Conversely to Mn-SOD alterations, which we observed after $\mathrm{NBO}-\mathrm{O}_{2}$ and $\mathrm{NBO}-\mathrm{O}_{2}{ }^{--}$treatment, the application of $\mathrm{NBO}-\mathrm{O}_{2}{ }^{\bullet+}$ did not exhibit any significant effect on this enzyme. This data further supports the view that enrichment of inhaled oxygen with oxygen cation markedly influences $\mathrm{NBO}$ effects on heart and other tissues and attenuates oxidative stress. Activities of mitochondrial enzymes showed different responses to applied NBO treatments. Marked loss in activity of cytochrome $c$ oxidase and especially cytochrome $c$ reductase after $\mathrm{NBO}-\mathrm{O}_{2}{ }^{--}$treatment suggests that these enzymes are more susceptible to oxidative damage then citrate synthase which was unchanged. Both enzymes of respiratory chain exhibited similar responses to NBO-
$\mathrm{O}_{2}$ and $\mathrm{NBO}-\mathrm{O}_{2}{ }^{\bullet+}$ treatment. In contrast, citrate synthase was stimulated only after $\mathrm{NBO}-\mathrm{O}_{2}{ }^{\bullet+}$ treatment. These results support our previous findings (Kaplan et al. 2009) that enrichment of inhaled $\mathrm{O}_{2}$ with oxygen cation might have beneficial effect on the enzymes of citric acid cycle, which plays a critical role in cardiac energy production. The mechanism of protection against LPO and stimulation of citrate synthase by $\mathrm{O}_{2}{ }^{\bullet+}$ is not clear. It possibly involves elimination of $\mathrm{O}_{2}{ }^{--}$or other ROS produced at hyperoxic conditions, but other non-radical mechanisms could also participate. Interestingly, the effect of $\mathrm{NBO}-\mathrm{O}_{2}{ }^{\bullet+}$ treatment on the guinea pig heart differs from that on brain, where 60 -h inhalation of $\mathrm{O}_{2}$ with oxygen cation stimulated both expression and activity of Mn-SOD (Tatarkova et al. 2011). Nevertheless, stimulation of other antioxidant enzymes in the heart, which were not investigated in the present study, cannot be excluded.

In conclusion, the data reported in this study suggest that long-term NBO treatment is associated with myocardial oxidative damage and attenuation of Mn-SOD activity. The adverse effects are partially attenuated by inhalation of $\mathrm{O}_{2}$ enriched with oxygen cation. These data indicate that application of $\mathrm{NBO}-\mathrm{O}_{2}{ }^{\bullet+}$ can optimize $\mathrm{NBO}$ therapy.

Acknowledgements. This work was partially supported by grants VEGA 1/0028/11 from the Ministry of Education and Science of the Slovak Republic and project "Identification of Novel Markers in Diagnostic Panel of Neurological Diseases", code:26220220114 co-financed from EC sources and European Regional Development Fund.

\section{References}

Ay H., Topal T., Özler M., Uysal B., Korkmaz A., Öter S., Ogur R., Dündar K. (2007): Persistence of hyperbaric oxygen-induced oxidative effects after exposure in rat brain cortex tissue. Life Sci. 80, 2025-2029 http://dx.doi.org/10.1016/j.lfs.2007.03.002

Babusikova E., Kaplan P., Lehotsky J., Jesenak M., Dobrota D. (2004): Oxidative modification of rat cardiac mitochondrial membranes and myofibrils by hydroxyl radicals. Gen. Physiol. Biophys. 23, 327-335

Bader N., Bosy-Westphal A., Koch A., Rimbach G., Weimann A., Poulsen H. E., Müller M. J. (2007): Effect of hyperbaric oxygen and vitamin $\mathrm{C}$ and $\mathrm{E}$ supplementation on biomarkers of oxidative stress in healthy men. Br. J. Nutr. 98, 826-833 http://dx.doi.org/10.1017/S0007114507744380

Bigdeli M. R., Rahnema M. (2009): The effect of normobaric hyperoxia on superoxide dismutase activity and neurological deficits in an animal model of Huntinngton disease. Physiol. Pharmacol. 13, 18-27

Boveris A., Chance B. (1973): The mitochondrial generation of hydrogen peroxide. General properties and effect of hyperbaric oxygen. Biochem. J. 134, 707-716

Brozmanova M., Plevkova J., Bartos V., Plank L., Javorka M., Tatar M. (2006): The interaction of dietary antioxidant vitamins and 
oxidative stress on cough reflex in guinea-pigs after long term oxygen therapy. J. Physiol. Pharmacol. 57, 45-54

Chavko M., Harabin A. L. (1996): Regional lipid peroxidation and protein oxidation in rat brain after hyperbaric oxygen exposure. Free Radic. Biol. Med. 20, 973-978 http://dx.doi.org/10.1016/0891-5849(95)02181-7

Dekleva M., Ostojic M., Neskovic A., Mazic S., Vlahovic A., Suzic Lazic J., Dekleva N. (2009): Early detection of myocardial viability by hyperbaric oxygenation in patients with acute myocardial infarction treated with thrombolysis. Gen. Physiol. Biophys. 28, 127-134

Dennong C., Radermacher P., Barnett Y. A., Speit G. (1999): Antioxidant status in humans after exposure to hyperbaric oxygen. Mutat. Res. 428, 83-89 http://dx.doi.org/10.1016/S1383-5742(99)00034-4

Dundar K., Topal T., Ay H., Oter S., Korkmaz A. (2005): Protective effects of exogenously administrated or endogenously produced melatonin on hyperbaric oxygen-induced oxidative stress in the rat brain. Clin. Exp. Pharmacol. Physiol. 32, 926-930 http://dx.doi.org/10.1111/j.1440-1681.2005.04286.x

Eken A., Aydin A., Sayal A., Ustündag A., Duydu Y., Dündar K. (2005):. The effects of hyperbaric oxygen treatment on oxidative stress and SCE frequencies in humans. Clin. Biochem. 38, 1133-1137 http://dx.doi.org/10.1016/j.clinbiochem.2005.09.001

Engler I., Atzmüeller C., Donic V., Steinhäusler F. (2009): Reactive oxygen species, especially $\mathrm{O} 2+\bullet$ in cancer mechanisms. J. Exp. Therapeut. Oncol. 8, 157-165

Gao Z., Spilk S., Momen A., Muller M. D., Leuenberger U. A., Sinoway L. I. (2012): Vitamin C prevents hyperoxia-mediated coronary vasoconstriction and impairment of myocardial function in healthy subjects. Eur. J. Appl. Physiol. 112, 483-492 http://dx.doi.org/10.1007/s00421-011-1997-x

Gregorevic P., Lynch G. S., Williams D. A. (2001): Hyperbaric oxygen modulates antioxidant enzyme activity in rat skeletal muscle. Eur. J. Appl. Physiol. 86, 24-27 http://dx.doi.org/10.1007/s004210100503

Hensley K., Howard B. J., Carney J. M., Butterfield D. A. (1995): Membrane protein alterations in rodent erythrocytes and synaptosomes due to aging and hyperoxia. Biochim. Biophys. Acta 1270, 203-206

Howard L. S. (2009): Oxygen therapy. Clin. Med. 9, 156-159

Kaplan P., Tatarkova Z., Engler I., Calkovska A., Mokra D., Drgova A., Kovalska M., Lehotsky J., Dobrota D. (2009): Effects of long- term oxygenation treatments on a-ketoglutarate dehydrogenase activity and oxidative modifications in mitochondria of guinea pig heart. Eur. J. Med. Res. 14, 116-120

MacMillan-Crow L. A., Crow J. P., Kerby J. D., Beckman J. S., Thompson J. A. (1996): Nitration and inactivation of manganese superoxide dismutase in chronic rejection of human renal allografts. Proc. Natl. Acad. Sci. U.S.A. 93, $11853-11858$ http://dx.doi.org/10.1073/pnas.93.21.11853

Moradkhan R., Sinoway L. I. (2010): Revisiting the role of oxygen therapy in cardiac patients. J. Am. Coll. Cardiol. 56, 1013-1016 http://dx.doi.org/10.1016/j.jacc.2010.04.052

Narkowicz C. K., Vial J. H., McCartney P. W. (1993): Hyperbaric oxygen therapy increases free radical levels in the blood of humans. Free Radic. Res. Commun. 19, 71-80 http://dx.doi.org/10.3109/10715769309056501

Nilakantan V., Halligan N. L. N., Nguyen T. K., Hilton G., Khanna A. K., Roza A. M., Johnson C. P., Adams M. B., Griffith O. W., Pieper G. M. (2005): Post-translational modification of manhanese superoxide dismutase in acutely rejecting cardiac transplants: role of inducible nitric oxide synthase. J. Heart Lung Transplant. 24, 1591-1599 http://dx.doi.org/10.1016/j.healun.2005.01.009

Nulton-Persson A. C., Szweda L. I. (2001): Modulation of mitochondrial function by hydrogen peroxide. J. Biol. Chem. 276, 23357-23361 http://dx.doi.org/10.1074/jbc.M100320200

Racay P., Tatarkova Z., Drgova A., Kaplan P., Dobrota D. (2009): Ischemia-reperfusion induces inhibition of mitochondrial protein synthesis and cytochrome c oxidase activity in rat hippocampus. Physiol. Res. 58, 127-138

Tatarkova Z., Engler I., Calkovska A., Mokra D., Drgova A., Hodas P., Lehotsky J., Dobrota D., Kaplan P. (2011): Effect of long-term normobaric hyperoxia on oxidative stress in mitochondria of the guinea pig brain. Neurochem. Res. 36, 1475-1481 http://dx.doi.org/10.1007/s11064-011-0473-7

Yamakura F., Kawasaki H. (2010): Post-translational modifications of superoxide dismutase. Biochim. Biophys. Acta 1804, $318-325$

Received: September 26, 2011

Final version accepted: February 29, 2012 